\title{
LOCALISING GLOBAL GOALS IN AUSTRALIA'S GLOBAL CITY: SYDNEY
}

\author{
ALISON HOLLOWAY \\ Principal and Partner SGS Economics and Planning, Australia
}

\begin{abstract}
The United Nations Sustainable Development Goals (SDGs) are universal, adopted by world leaders to provide an ambitious 15-year outlook across social, economic and environmental objectives. They offer a cross-disciplinary approach to respond to a rapidly changing global environment. The UN recognises the importance of cities in achieving the SDGs. More than half of the world's inhabitants live in cities and this is a trend that will continue. This integrated and long-term approach to addressing development is not new to city and regional strategic planning practices. Strategic urban planning practices adopt a process of research, setting mechanisms, implementation, monitoring and evaluation to work towards a preferred economic and social geography of the city. Strategic planning for cities has a lead role in connecting the global aspirations in the SDGs to local action. At a simple level, measuring and monitoring a consistent set of indicators - such as the SDGs - will highlight important spatial differences that national reporting cannot distinguish. However, ad-hoc SDG plans will not realise the full potential of the SDG framework. Achieving the SDGs goals and targets will require alignment with existing local processes for integrated spatial planning and investment. This paper draws on Australian strategic planning for cities. In particular, Greater Sydney and the role of both the newly established Greater Sydney Commission and local governments through community strategic plans. Greater Sydney - as Australia's global city - has a major national role in reaching the ambitious SDG targets. This requires reflection on local circumstances, through evidence based research and public input, to identify needs and priorities backed up with actions to deliver real change. These actions need to be supported by a comprehensive indicator and performance management framework to focus implementation, allocate resources and provide greater accountability. Achievement of the SDGs requires a local response and the urban planning profession has a lead role.

Keywords: sustainable development indicators, UN sustainable development goals, governance, city planning, strategic planning, Sydney.
\end{abstract}

\section{INTRODUCTION}

The United Nations Sustainable Development Goals (SDGs) were adopted by world leaders to provide an ambitious 15-year outlook for sustainable development. They offer a crossdisciplinary approach to respond to a rapidly changing global environment. Australia, as a UN member, has adopted the SDGs which came into effect in January 2016. There are 17 goals (see Fig. 1), 169 targets and 231 indicators [1].

The SDGs goals and targets cannot be achieved at the global and national level, without aligning local processes for integrated spatial planning and investment. Despite the goals being global and universal, their achievement requires action at the local and city level. The UN recognises the importance of cities in achieving the SDGs. More than half of the world's inhabitants live in cities [2] and this is a trend that will continue. The inclusion of Goal 11: Make cities inclusive, safe, resilient and sustainable brings a spatial focus to the goals and is in response to this major movement towards cities.

In Australia, the population of the eight Greater Cities combined is 67 percent of Australia's population, and growth in these Greater Cities in 2015-16 accounted for 85 percent of national population growth [3]. This paper draws on Australian strategic planning for cities, in particular, Greater Sydney. It outlines a role of both the newly established Greater Sydney Commission and local governments, through community strategic plans to 

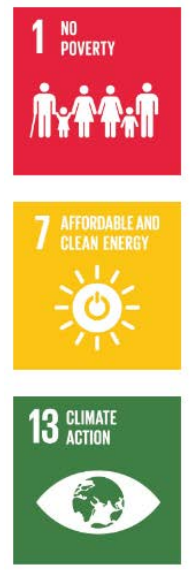
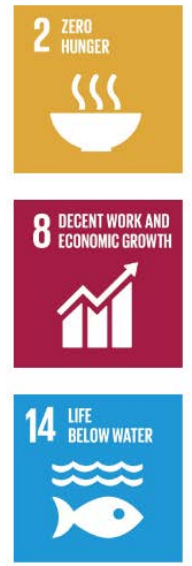
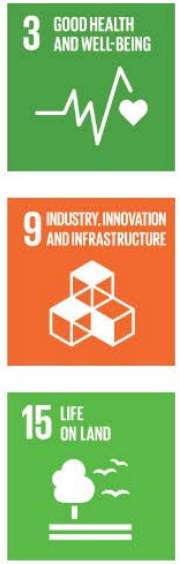
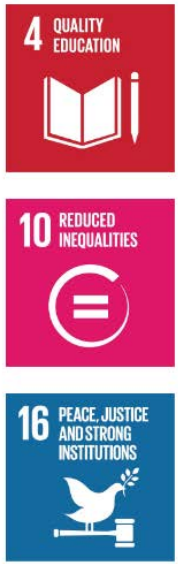
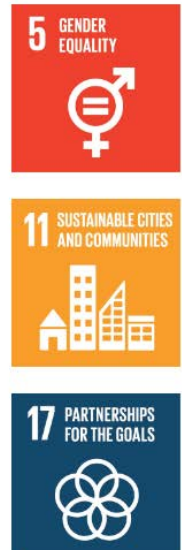
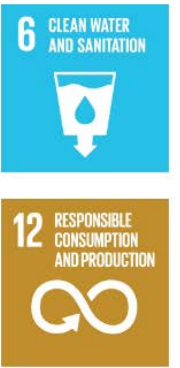

(9) SUSTAINABLE GEVIS ALS

Figure 1: The 17 Sustainable Development Goals [1].

act on the SDGs. While the SDGs are global, achievement relies on a local spatial response and the urban planning profession can have a lead role.

\section{GLOBAL GOALS, CITIES AND STRATEGIC PLANNING}

\subsection{What do the UN SDG's offer?}

The SDGs are intended to guide governments, not for profit organisations and companies in responding to social, economic and environmental issues. Since their release, the SDGs have been critiqued across a range of issues. The large quantity of goals, is challenged as attempting to cover too much ground. The targets are also critiqued as spreading the focus too thin and as being too aspirational to affect real change. The goals are complex as they recognize the multifaceted and structural problems that they seek to address at a global level. There is also strong critique over the implementability and measurability of many of the targets. In research coordinated by the International Council for Science (ICSU), in partnership with the International Social Science Council (ISSC), it was reported that out of the 169 targets, 49 (29\%) are considered well developed, 91 targets (54\%) could be strengthened by being more specific, and 29 (17\%) require significant work [4]. Despite these critiques, this paper proposes that the SDGs offer two things for strategic planning for cities:

Firstly, the SDG's provide a common language and stretch agenda for scoping policy. They provide clear high level shared global priorities and a basis for reflecting on local circumstances, needs and focus, informed by sound evidence. The process of localising global goals is an important initial step to assess the alignment of global and national targets with local issues [5]. As there are so many cross dependencies between the SDGs, is only at the place level that these can be readily resolved and prioritised. Not all 17 SDGs will be equally important or even relevant across all jurisdictions. Some of the goals and targets remain specific to developing nations and contexts. This process is strategic, informed by evidence to focus efforts and identify the goals most relevant to the local area. Once these high-level goals are 


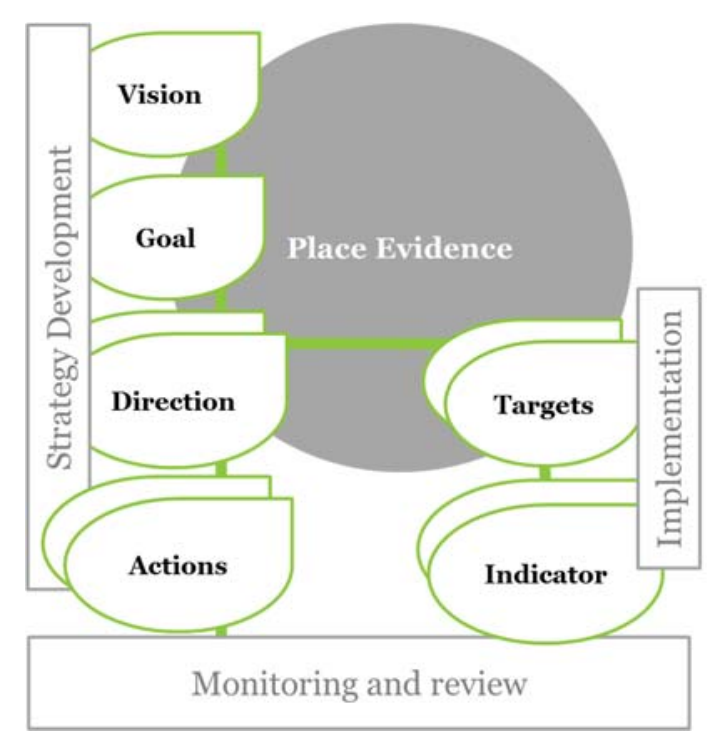

Figure 2: Overview of typical strategic planning process.

2. agreed, the focus can then be on the best local responses to meet locally appropriate targets.

3. Secondly, they provide a clear monitoring and review framework that can provide greater accountability to support implementation. Local level monitoring can provide a stronger connection between actions and outcomes. A clear monitoring and review framework has a role in aligning priorities and allocating resources.

\subsection{Strategic planning for cities}

The integrated and long-term approach to addressing development provided by the SDGs is not new to city and regional strategic planning practice. There are existing practices across strategic planning for cities that can be used to identify the scope of local issues and a monitoring and review framework. Strategic planning for cities offers a critical link between global aspirations in the SDGs to local action.

Strategic planning for cities generally adopts a process of research, setting mechanisms, implementation, monitoring and review to work towards a vision - that is, a preferred economic and social geography of the city. This general practice is outlined in Fig. 2. The practice is based on the following components: Strategy development, implementation and monitoring and review. Further detail on these elements is expanded in the following sections.

\subsubsection{Strategy Development}

The strategy development step includes four elements:

- Place evidence: provides a baseline on the existing situation and future trends across key themes of housing, population, economy and employment, transport, open space, environmental protection, natural resource management and governance (among others depending on local circumstances). This step includes research and 
data collection, including engagement with communities and other stakeholders. The SDGs can guide the scope of data collection for place evidence, this will inform relevant issues that the strategy development needs to cover.

- Vision: a preferred economic and social geography of the city, that is both aspirational and achievable, typically over a 15-30-year timeframe.

- Goals: the outcome being sought over the strategy timeframe. It's a specific end result that define what success means.

- Directions: the approach to reaching the goal. It provides the detail of the progress needed to reach the goal. The direction should describe the issues that are being addressed.

\subsubsection{Implementation}

Implementation is based on addressing the issues scoped in the directions with a series of specific actions. These actions can cover a range of mechanisms including land use regulation, transport investment, economic development, education and marketing, affordable housing, land market programs or pricing that are delivered through state, metropolitan and local governance. The actions can be translated into an implementation plan detailing who is responsible, when the action will be undertaken, and the resources required.

They also provide a framework for aligning local targets and indicators to establish consistent approaches to data collection to contribute to national level reporting and greater transparency.

\subsubsection{Monitoring and review framework}

Once the scope of the relevant goals is identified, the targets and indicators can be aligned. Targets relate to a specific direction and set a measurable outcome being sought. The indicators or the outcome measure, is a way of ascertaining whether direction is being met. Monitoring these indicators provide an opportunity to review effectiveness of actions and reallocate resources. It is often this final step of setting targets and indicators as part of a monitoring and review process that is excluded from strategic spatial planning. In preparing relevant indicators, consideration should be given to:

- indicators having clear links to directions

- $\quad$ avoiding repetition across indicators

- include a 'baseline' figure and recent trends for each indicator

- applying an 'annual' and a 'medium term' reporting approach (5-10 years), and

- identifying if the reporting agency has control (policy areas in direct control of the reporting agent), influence (issues which the reporting agent does not control but can influence), or concern (those areas which the reporting agent doesn't control or influence but are of concern to the community) over achievement of the targets [6].

A robust framework for measuring and reporting progress provides quality information to the community, other government agencies and industry on the performance of a city/local area. It provides an understanding of recent and emerging trends. By presenting indicators in an accessible online dashboard format it promotes transparency and greater accountability in decision-making. This approach better defines the relationship between the goals and actions, by readily tracking how implementation is progressing and if the approach is effective. Each jurisdiction can set its own targets guided by the global level of ambition but taking into account local circumstances and the spatial scale of issues being considered. 


\section{THE SDG'S AND SYDNEY: AUSTRALIA'S GLOBAL CITY}

\subsection{Greater Sydney in context}

Sydney is Australia's only global city with a population of 5.05 million (2016), and making up 21 percent of Australia's population [3]. In 2016, Sydney's GDP of \$400.9 billion represented almost a quarter of national GDP. Sydney's GDP growth rate of 4.5 percent was the highest in over 15 years. Sydney contributed 38.6 percent of national GDP growth, the highest in 25 years [7].

Australia has a constitutional, two-tiered system of government, with national government, six states and two territory governments. Greater Sydney is the capital of New South Wales, and is made up of 30 local governments. Local government is not constitutionally recognised; their power derives from either the Commonwealth or State/Territory governments. State/Territory governments are largely responsible for land management, with certain of those powers and responsibilities delegated to local authorities. The Commonwealth has limited direct effect on state planning [8].

The Australian Government released the Smart Cities Plan in 2016 [9]. It 'sets out the Australian Government's vision for our cities, and our plan for maximising their potential'. The plan covers six domains; infrastructure and investment, jobs and skills, liveability and sustainability, innovation and digital opportunities, governance, city planning and regulation, and housing affordability and supply. The plan does not reference the SDGs or the New Urban Agenda [10]. However, it does include a data and indicators framework with priorities to "collect and analyse data about the performance of our cities, so we can measure our policies' success and respond to new needs".

The limited direct effect of the national government on state planning, means that they are unlikely to have an influence on many of the spatial outcomes that will directly influence the achievement of the SDGs with the current approach. This is despite, a strong case for national urban policy based on the demonstrated connections between the pattern of urban development and Australia's economic performance, social inclusion and environmental performance. All matters of national interest and international responsibilities. The tools outlined in Section 2.2 are limited at the national level, where responsibility for reporting on the SDGs currently lies. While the response needs to be multi-faceted, a city-based and local response of integrated spatial planning and investment, can have a significant contribution. This approach is developed further in the following sections.

\subsection{Strategic planning in Greater Sydney}

Within Sydney, the establishment of the Greater Sydney Commission (GSC) in 2016 presents a unique opportunity to shape Sydney's future. The Greater Sydney Commission's role is to coordinate and align the planning that will shape the future of Greater Sydney. It is an independent organisation funded by the NSW Government.

Sydney is poised to be a city of seven million people by 2051, an increase of 40 percent in just 25 years. Significant shifts in the current way going about metropolitan planning is needed to support the expected scale of activities across the city and address the resultant social, economic and environmental challenges. The approach to strategic planning is described in the following section.

The NSW Government tasked the Greater Sydney Commission (GSC) with a Ministerial Statement of Priorities to guide its first three years in operation [11]. One priority is that the 
GSC will "consider and integrate the 2015 Sustainable Development Goals (SDGs) recently adopted by Australia as a member of the United Nations (UN)".

In 2017, the GSC will prepare a regional plan for the Greater Sydney that combines a review of a Plan for Growing Sydney (2014), the NSW Long Term Transport Masterplan (2012) and Rebuilding NSW - State Infrastructure Strategy (2014). This review provides an opportunity for the GSC to reflect on the SDGs and identify opportunities for these to be integrated and aligned. The review should not only consider the goals and targets, but also the implementation and monitoring framework that supports them.

The GSC recently released Towards our Greater Sydney 2056 a draft amendment to the Region Plan a Plan for Growing Sydney that includes a vision, metropolitan priorities and outcomes (Table 1). At the same time, six Draft District Plans were released that include housing supply targets, affordable housing targets for rezoning and jobs targets for employment in centres. The vision and plans are supported by an online Dashboard to monitor growth and change in Greater Sydney. All of these elements (priorities, outcomes, targets, and a dashboard) are positive building blocks for a more comprehensive indicator and performance management framework as part of the Greater Sydney Region Plan update being prepared in 2017. Building on this approach, the updated Region Plan could identify clear measurable performance targets at the metropolitan level across productivity, liveability and sustainability aligned to the SDGs. The indicators would be localised and specific to circumstances in Greater Sydney.

A high level of mapping the SDGs against the metropolitan priorities in Towards Our Greater Sydney 2056 is provided in Table 2. The mapping process shows just one of the 17 goals as out of scope for a metropolitan strategy in a developed global city. There are two goal areas that given limited or no consideration within the metropolitan priorities in Towards Our Greater Sydney 2056. Of the remaining Goals, there are metropolitan priorities noted in Towards Our Greater Sydney 2056 that provide an entry point for developing measurable targets and indicators. The table highlights the potential additional elements that could further consider the SDG's and supporting targets and indictors. Consideration of these in the design and assessment of settlement patterns and infrastructure could better inform priorities.

\subsection{Local Government in NSW and Greater Sydney}

In Greater Sydney, there are 41 Local Government Areas, each is required to develop a Community Strategic Plan as set out in the Local Government Act [12]. A community strategic plan is a plan that identifies the main priorities and aspirations for the future of the local government area covering a period of at least 10 years from when the plan is endorsed. It sits above all other plans and policies, including a four-year delivery program and an annual operational plan. It needs to establish strategic objectives together with strategies for achieving those objectives. They are required to give regard to relevant state and regional plans, including plans prepared by the Greater Sydney Commission.

There is a requirement in the Act to review the Plan and report on progress annually. There is a minimum expectation that some form of measurement exists, including the setting of targets and indicators to report on objectives/activities. The City of Sydney's Sustainable Sydney 2030 Vision [13] is sound example of an integrated strategic planning process, informing a local community strategic plan, with a clear performance monitoring program. The requirements for a local government Community Strategic Plan, mean that the governance frameworks are in place to support the integration of the SDGs at the local level, while reflecting and responding to local circumstances, needs and priorities. 
Table 1: Metropolitan priorities and aims for Greater Sydney [11].

\begin{tabular}{|c|c|c|}
\hline Productive City & Liveable City & A Sustainable City \\
\hline $\begin{array}{l}\text { A growing city } \\
\text { - support the generation } \\
\text { of over } 817,000 \\
\text { additional jobs } \\
\text { • accommodate } 1.74 \\
\text { million additional } \\
\text { people and more than } \\
725,000 \text { new homes } \\
\text { - increase Greater } \\
\text { Sydney's economic } \\
\text { growth rate } \\
\text { - increase total } \\
\text { economic activity by } \\
75 \% \text { to approximately } \\
\$ 655 \text { billion. } \\
\end{array}$ & $\begin{array}{l}\text { An equitable, polycentric city } \\
\text { - provide equitable access to jobs and } \\
\text { education in centres to strengthen human } \\
\text { capital } \\
\text { - deliver a more equitable city by planning } \\
\text { for infrastructure as growth occurs } \\
\text { - provide equitable access to health, open } \\
\text { space and community and cultural } \\
\text { infrastructure } \\
\text { - respect and enhance heritage areas and } \\
\text { assets } \\
\text { - understand the impact of demographic } \\
\text { changes such as higher proportions of both } \\
\text { school-aged children and the frail aged. }\end{array}$ & $\begin{array}{l}\text { A city in its landscape } \\
\text { - improve the health of } \\
\text { waterways } \\
\text { - protect, extend and } \\
\text { enhance biodiversity, } \\
\text { regional and local open } \\
\text { space systems, as well } \\
\text { as scenic and cultural } \\
\text { heritage together with } \\
\text { productive landscapes } \\
\text { - increase access to } \\
\text { open space, conserve } \\
\text { the natural environment } \\
\text { and enable healthy } \\
\text { lifestyles and local food. }\end{array}$ \\
\hline $\begin{array}{l}\text { A city with smart jobs } \\
\text { - increase knowledge- } \\
\text { intensive jobs and } \\
\text { health and education } \\
\text { jobs } \\
\text { - increase productivity } \\
\text { per worker } \\
\text { - focus on international } \\
\text { students and inbound } \\
\text { tourism } \\
\text { - deliver a smart city } \\
\text { that enables knowledge- } \\
\text { intensive jobs to thrive. }\end{array}$ & $\begin{array}{l}\text { A city of housing choice and diversity } \\
\text { - support a range of housing choices at } \\
\text { different price points to suit people through } \\
\text { all stages of life } \\
\text { - provide affordable rental housing } \\
\text { specifically for eligible households on very } \\
\text { low and low incomes } \\
\text { - support the delivery of the NSW } \\
\text { Government's social housing program } \\
\text { - increase housing supply that broadens } \\
\text { choice and diversity } \\
\text { - locate more jobs close to where people } \\
\text { live } \\
\text { - in existing areas, prioritise new housing in }\end{array}$ & $\begin{array}{l}\text { ient city } \\
\text { ise and mitigate } \\
\text { mental impacts } \\
\text { the efficient use } \\
\text { y and resources, } \\
\text { g of water and } \\
\text { s together with } \\
\text { lopment of } \\
\text { le energy }\end{array}$ \\
\hline $\begin{array}{l}\text { A 30-minute city } \\
\text { - increase the } \\
\text { proportion of people } \\
\text { with good access to jobs } \\
\text { and prioritise socially } \\
\text { disadvantaged areas } \\
\text { - improve accessibility } \\
\text { to jobs across all } \\
\text { districts } \\
\text { - improve the ability to } \\
\text { walk to local services } \\
\text { and amenities. }\end{array}$ & $\begin{array}{l}\text { A collaborative city } \\
\text { - achieve pathways for collaborative and } \\
\text { shared use of social infrastructure, } \\
\text { community resources and underutilised } \\
\text { public assets such as schools, open spaces } \\
\text { and residual government owned land to } \\
\text { promote liveability, quality of life and } \\
\text { resource efficiency } \\
\text { - ensure our collaborations enhance quality } \\
\text { of life across the widest possible area } \\
\text { - lead the collaboration in the development } \\
\text { of major city-shaping areas, such as the } \\
\text { Western Sydney Airport and GPOP } \\
\text { - increase, through the Greater Sydney } \\
\text { Dashboard, ways for the community to } \\
\text { access data and knowledge to help them to } \\
\text { co-create a Greater Sydney. }\end{array}$ & $\begin{array}{l}\text { A resilient city } \\
\text { - identify and adapt to } \\
\text { the impacts of climate } \\
\text { change that are likely to } \\
\text { increase } \cdot \text { minimise } \\
\text { exposure to manmade } \\
\text { and natural hazards } \\
\text { - strengthen social, } \\
\text { organisational and } \\
\text { infrastructure capacity } \\
\text { by addressing chronic } \\
\text { stresses in order to be } \\
\text { able to resist and rebuild } \\
\text { after the acute shock of } \\
\text { natural disasters. }\end{array}$ \\
\hline
\end{tabular}


Table 2: Alignment of sustainable development goals with metropolitan priorities for Greater Sydney.

\begin{tabular}{|c|c|c|c|}
\hline $\begin{array}{l}\text { Sustainable Development } \\
\text { Goals, and description }\end{array}$ & $\begin{array}{l}\text { Most relevant } \\
\text { themes from SDG } \\
\text { targets for Greater } \\
\text { Sydney Vision }\end{array}$ & \begin{tabular}{|l|} 
Towards Our \\
Sydney 2056, \\
Relevant \\
Metropolitan \\
Priorities (see \\
Table 1) \\
\end{tabular} & $\begin{array}{l}\text { Potential additional strategy } \\
\text { elements to consider the goal and } \\
\text { indicators }\end{array}$ \\
\hline $\begin{array}{l}\text { 1. No poverty } \\
\text { End poverty in all its forms } \\
\text { everywhere }\end{array}$ & $\begin{array}{l}\text { Access to basic } \\
\text { services. }\end{array}$ & $\begin{array}{l}\text { An equitable, } \\
\text { polycentric city. }\end{array}$ & $\begin{array}{l}\text { Spatial variations to inform } \\
\text { infrastructure and services } \\
\text { priorities and settlement patterns. }\end{array}$ \\
\hline $\begin{array}{l}\text { 2.Zero hunger } \\
\text { End hunger, achieve food } \\
\text { security and improved } \\
\text { nutrition and promote } \\
\text { sustainable agriculture } \\
\end{array}$ & Out of scope. & No consideration. & $\begin{array}{l}\text { Consideration of links to regional } \\
\text { food production economies, } \\
\text { planning support to community } \\
\text { gardens. }\end{array}$ \\
\hline $\begin{array}{l}\text { 3.Good health and wellbeing } \\
\text { Ensure healthy lives and } \\
\text { promote well-being for all at } \\
\text { all ages }\end{array}$ & $\begin{array}{l}\text { Road traffic accidents. } \\
\text { Air quality. }\end{array}$ & $\begin{array}{l}\text { An equitable, } \\
\text { polycentric city } \\
\text { A resilient city. }\end{array}$ & $\begin{array}{l}\text { Spatial variations to inform } \\
\text { infrastructure and services } \\
\text { priorities and settlement patterns. } \\
\text { Focus on active and public } \\
\text { transport. Consideration of relevant } \\
\text { indicators in evaluation methods. }\end{array}$ \\
\hline \begin{tabular}{|l|} 
4.Quality education \\
Ensure inclusive and \\
equitable quality education \\
and promote lifelong \\
learning opportunities for all \\
\end{tabular} & Access to education. & $\begin{array}{l}\text { An equitable, } \\
\text { polycentric city }\end{array}$ & $\begin{array}{l}\text { Spatial variations to inform } \\
\text { infrastructure priorities and } \\
\text { settlement patterns that influence } \\
\text { outcomes. }\end{array}$ \\
\hline $\begin{array}{l}\text { 5. Gender equality } \\
\text { Achieve gender equality and } \\
\text { empower all women and } \\
\text { girls }\end{array}$ & $\begin{array}{l}\text { Shared } \\
\text { responsibilities. } \\
\text { Provision of } \\
\text { infrastructure. } \\
\text { Equal rights to } \\
\text { economic resources. } \\
\end{array}$ & $\begin{array}{l}\text { Limited } \\
\text { consideration. }\end{array}$ & $\begin{array}{l}\text { Spatial variations to inform } \\
\text { infrastructure priorities and } \\
\text { settlement patterns. }\end{array}$ \\
\hline $\begin{array}{l}\text { 6. Clean water and sanitation } \\
\text { Ensure availability and } \\
\text { sustainable management of } \\
\text { water and sanitation for all }\end{array}$ & $\begin{array}{l}\text { Health of waterways. } \\
\text { Water use efficiency. }\end{array}$ & $\begin{array}{l}\text { A city in its } \\
\text { landscape. } \\
\text { An efficient city. }\end{array}$ & Infrastructure priorities. \\
\hline $\begin{array}{l}\text { 7. Affordable and clean } \\
\text { energy } \\
\text { Ensure access to affordable, } \\
\text { reliable, sustainable and } \\
\text { modern energy for all } \\
\end{array}$ & $\begin{array}{l}\text { Efficient use of } \\
\text { energy. }\end{array}$ & An efficient city. & Infrastructure priorities. \\
\hline $\begin{array}{l}\text { 8. Decent work and } \\
\text { economic growth } \\
\text { Promote sustained, inclusive } \\
\text { and sustainable economic } \\
\text { growth, full and productive } \\
\text { employment and decent } \\
\text { work for all } \\
\end{array}$ & $\begin{array}{l}\text { Economic growth. } \\
\text { Tourism growth. } \\
\text { Participation rates. }\end{array}$ & $\begin{array}{l}\text { A growing city } \\
\text { A city with smart } \\
\text { jobs. } \\
\text { A } 30 \text {-minute city. }\end{array}$ & $\begin{array}{l}\text { Spatial variations to inform } \\
\text { infrastructure priorities and } \\
\text { settlement patterns. }\end{array}$ \\
\hline $\begin{array}{l}\text { 9. Industry, innovation and } \\
\text { infrastructure. } \\
\text { Build resilient infrastructure, } \\
\text { promote inclusive and } \\
\text { sustainable industrialization } \\
\text { and foster innovation } \\
\end{array}$ & $\begin{array}{l}\text { Emissions. } \\
\text { Innovation. }\end{array}$ & $\begin{array}{l}\text { A growing city. } \\
\text { A city with smart } \\
\text { jobs. } \\
\text { A resilient city. }\end{array}$ & Infrastructure priorities. \\
\hline
\end{tabular}


Table 2: Continued

\begin{tabular}{|c|c|c|c|}
\hline $\begin{array}{l}\text { 10. Reduced inequalities } \\
\text { Reduce inequality within } \\
\text { and among countries }\end{array}$ & $\begin{array}{l}\text { Income growth of } \\
\text { bottom } 40 \% \text { of } \\
\text { population. . }\end{array}$ & No consideration. & $\begin{array}{l}\text { Spatial variations to inform } \\
\text { infrastructure and services } \\
\text { priorities and settlement patterns. } \\
\text { Addressed through housing } \\
\text { affordability measures. }\end{array}$ \\
\hline $\begin{array}{l}\text { 11. Sustainable cities and } \\
\text { communities } \\
\text { Make cities and human } \\
\text { settlements inclusive, safe, } \\
\text { resilient and sustainable }\end{array}$ & $\begin{array}{l}\text { Safe and affordable } \\
\text { housing. } \\
\text { Access to green } \\
\text { space. } \\
\text { Mitigation and } \\
\text { adaptation to climate } \\
\text { change. } \\
\text { Cultural and natural } \\
\text { heritage }\end{array}$ & $\begin{array}{l}\text { A city of housing } \\
\text { choice and } \\
\text { diversity. } \\
\text { A city in its } \\
\text { landscape. } \\
\text { A resilient city. } \\
\text { An equitable, } \\
\text { polycentric city. }\end{array}$ & $\begin{array}{l}\text { Evidence to quantify demand } \\
\text { across housing sub-markets and } \\
\text { setting targets including for social } \\
\text { and affordable housing, by District } \\
\text { to address need. } \\
\text { Measures to provide a liveability } \\
\text { benefit with increases in } \\
\text { population. }\end{array}$ \\
\hline $\begin{array}{l}\text { 12. Responsible } \\
\text { consumption and production } \\
\text { Ensure sustainable } \\
\text { consumption and production } \\
\text { patterns }\end{array}$ & $\begin{array}{l}\text { Efficient use of } \\
\text { natural resources. }\end{array}$ & An efficient city. & $\begin{array}{l}\text { Infrastructure priorities and } \\
\text { settlement patterns. }\end{array}$ \\
\hline $\begin{array}{l}\text { 13. Climate action } \\
\text { Take urgent action to } \\
\text { combat climate change and } \\
\text { its impacts }\end{array}$ & $\begin{array}{l}\text { Adaptation and } \\
\text { resilience. }\end{array}$ & A resilient city. & $\begin{array}{l}\text { Infrastructure priorities and } \\
\text { settlement patterns. }\end{array}$ \\
\hline $\begin{array}{l}\text { 14. Life below water } \\
\text { Conserve and sustainably } \\
\text { use the oceans, seas and } \\
\text { marine resources for } \\
\text { sustainable development }\end{array}$ & $\begin{array}{l}\text { Marine pollution. } \\
\text { Protect marine and } \\
\text { coastal ecosystems. }\end{array}$ & $\begin{array}{l}\text { A city in its } \\
\text { landscape. } \\
\text { A resilient city. }\end{array}$ & $\begin{array}{l}\text { Additional focus on Sydney } \\
\text { Harbour, Rivers and beaches. }\end{array}$ \\
\hline $\begin{array}{l}\text { 15. Life on land } \\
\text { Protect, restore and promote } \\
\text { sustainable use of terrestrial } \\
\text { ecosystems, sustainably } \\
\text { manage forests, combat } \\
\text { desertification, and halt and } \\
\text { reverse land degradation and } \\
\text { halt biodiversity loss }\end{array}$ & Biodiversity. & $\begin{array}{l}\text { A city in its } \\
\text { landscape. }\end{array}$ & $\begin{array}{l}\text { Settlement patterns to consider } \\
\text { biodiversity implications. }\end{array}$ \\
\hline $\begin{array}{l}\text { 16. Peace, justice and strong } \\
\text { institutions } \\
\text { Promote peaceful and } \\
\text { inclusive societies for } \\
\text { sustainable development, } \\
\text { provide access to justice for } \\
\text { all and build effective, } \\
\text { accountable and inclusive } \\
\text { institutions at all levels }\end{array}$ & $\begin{array}{l}\text { Public safety. } \\
\text { Satisfaction with } \\
\text { public services. }\end{array}$ & $\begin{array}{l}\text { A collaborative } \\
\text { city. }\end{array}$ & $\begin{array}{l}\text { Directions on local design tailored } \\
\text { to local assets. Transparency in } \\
\text { decision making supported by } \\
\text { evaluation methods. }\end{array}$ \\
\hline $\begin{array}{l}\text { 17. Partnerships for the } \\
\text { objectives. } \\
\text { Strengthen the means of } \\
\text { implementation and } \\
\text { revitalize the global } \\
\text { partnership for sustainable } \\
\text { development }\end{array}$ & $\begin{array}{l}\text { Encourage and } \\
\text { promote effective } \\
\text { public, public-private } \\
\text { and civil society } \\
\text { partnerships. Capacity } \\
\text { building on data and } \\
\text { statistics. }\end{array}$ & $\begin{array}{l}\text { A collaborative } \\
\text { city. }\end{array}$ & $\begin{array}{l}\text { Stronger links between data } \\
\text { dashboard and policy outcomes, } \\
\text { along with integration of indicators } \\
\text { and reporting with local } \\
\text { government as major partner. }\end{array}$ \\
\hline
\end{tabular}

\subsection{Aligning local action with global goals}

Sydney has the opportunity to lead the Australian national contribution to global goals through integration of the SDGs into strategic urban planning practices. Australia cannot 
make progress towards the global goals without local action. Aligning the existing approaches for national, regional and local plans with the goals, target and indicators in the SDGs offers a much more effective approach than ad-hoc SDG plans.

Localising the SDGs from global goals to ones relevant at the metropolitan scale, will provide a consistent set of targets that local governments could also address in their 10-year Community Strategic Plans. This provides a common and nested approach to national reporting. Applying a common set of indicators also allows for comparative 'benchmarks' in other local government areas or even across cities. This allows for the performance of each place to be understood in a broader context. The SDGs framework allows for indicators, to be adapted to each location needs and contexts.

This approach could provide a future where national, regional and local government priorities are working towards clear and common goals. Sydney is driving Australia's economic growth, it also has an opportunity to drive sustainable development and Australia's contribution towards the UN Global Goals. The current frameworks for Sydney's strategic planning from the national, through state to local planning is shown in Fig. 3. At each of these scales, the tools exist to allow the SDGs to sit above as a common language for scoping local policy issues and to provide a clear, integrated monitoring and review framework.

\section{CONCLUSION}

This paper identifies the critical link between the achievement of the UN SDGs and Australian strategic planning for cities, in particular, planning for Greater Sydney and the role of local governments through Community Strategic Plans. Greater Sydney - as Australia's global city - has a major role in Australia's contribution to ambitious SDG's and associated targets. This requires reflection on local circumstances, through evidence based research and public input, to identify needs and priorities backed up with actions to deliver real change. These actions need to be supported by a comprehensive indicator and performance management framework to focus implementation, allocate resources and

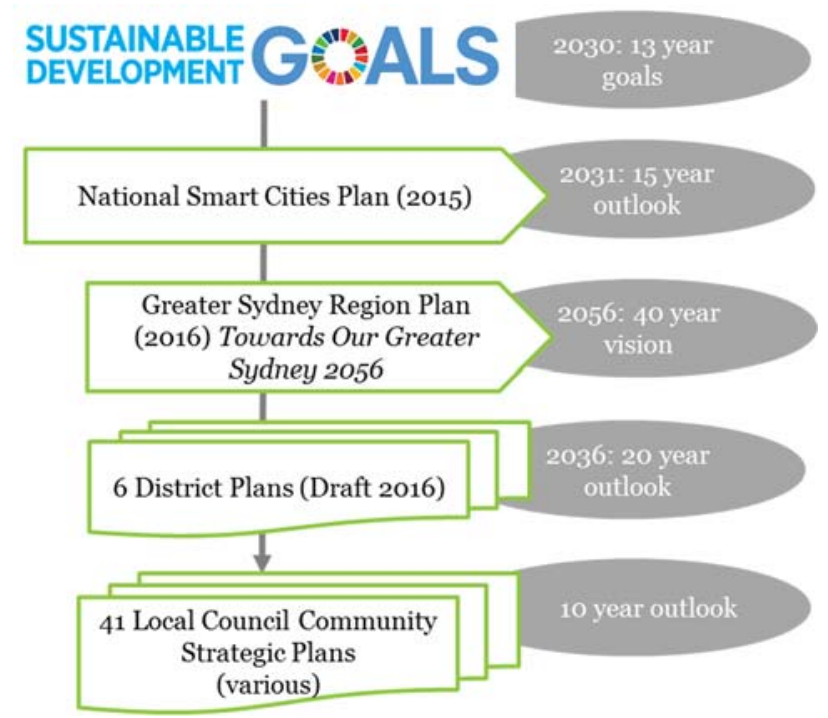

Figure 3: The hierarchy of aligning local action with Global Goals in Greater Sydney, and timeframes. 
provide greater accountability. Achievement of the SDGs requires a local response and the urban planning profession has the existing tools and capabilities to take a lead role.

\section{ACKNOWLEDGEMENTS}

This research paper and conference attendance was supported by SGS Economics and Planning Partner Sabbatical Program. I would like to thank Patrick Fensham, SGS Principal and Partner for an early draft review.

\section{REFERENCES}

[1] UN Sustainable Development Goals, Online. https://sustainabledevelopment. un.org/sdgs

[2] http://www.un.org/sustainabledevelopment/cities/

[3] Australian Bureau of Statistics Cat No. 3218.0 - Regional Population Growth, Australia, 2015-16.

[4] ICSU, ISSC Review of the Sustainable Development Goals: The Science Perspective. International Council for Science (ICSU): Paris, p. 6, 2015.

[5] Global Taskforce of local and regional governments, Roadmap for localizing the SDGs: Implementation and monitoring at subnational level, 2016.

[6] Based on City of Sydney, Community Wellbeing Indicators Framework, developed by ISF, 2016.

[7] SGS Economics and Planning, Sydney's growing economy - Who is being left behind? Online. https://www.sgsep.com.au/news/latest-news/sydneys-growingeconomy-who-being-left-behind. Accessed on: 1 Mar. 2017.

[8] McFarland, P., A Tale of Two Cities: Sydney and Melbourne's growth strategies and the flawed city-centric approach. University of New England, Armidale, New South Wales, SOAC, 2013.

[9] Commonwealth of Australia, Smart Cities Plan, 2016.

[10] UN Habitat 3 New Urban Agenda, Quito, 2016 http://habitat3.org/wpcontent/uploads/New-Urban-Agenda-GA-Adopted-68th-Plenary-N1646655-E.pdf Accessed on: 1 Mar. 2017

[11] Ministerial Statement of Priorities for the Greater Sydney Commission, January 2016.

[12] NSW Division of Local Government, Department of Premier and Cabinet, Government, Integrated Planning and Reporting Manual for local government in NSW, Mar. 2013

[13] City of Sydney, Sustainable Sydney 2030, Green, Global, Connected, 2008. 